\title{
Studies in a Dying Culture: Kemalist Columnists' Coverage of the Kurdish Peace Initiative
}

\author{
By Aysun Akan* \\ Zafer Fehmi Yörük ${ }^{\dagger}$
}

The founding ideology of the Turkish Republic, Kemalism, is based on homogenisation of an ethnically and religiously diverse population, aiming, ultimately to create a modern secular nation. Kemalist assimilation policies alienated the minorities, most notably the Kurds, Turkey's largest ethnic minority. The Kurds' demands of official recognition of their ethnic status met with strong military violence. Despite denial and suppression in the 1920s and 1930s, the Kurdish question has become a critical issue since the 1980s, when the Kurdish guerrilla movement, the PKK, launched an armed struggle against the military. In 2009, the Justice and Development Party (AKP) government initiated the 'Kurdish opening' process as an attempt to find a peaceful solution to the Kurdish problem which ended in failure due to the government's unwillingness to pursue the peace plan in the face of the growing opposition against negotiations with the PKK. A second initiative by the government was launched in 2012, when the government officials began to negotiate with the jailed Kurdish leader Abdullah Öcalan. This 'peace process' has caused a controversial debate between the pro-government and Kemalist media institutions. Kemalist reporters and writers argue that the government's peace plan is the beginning of an end to Turkey's national unity. Moreover, holding talks with Öcalan, who is nicknamed as the 'head of terrorists' and 'baby killer', in the mainstream media, is presented as the biggest assault on Turkish nationalism and a compromise of the founding principles of the Republic of Turkey, most notably, the principle of 'one state, one nation, one flag, one language'. For the Kemalist journalists, the threat posed by the Kurdish solution process to the unity of nation doubled by the fact that it is initiated by the AKP government, since AKP represents a serious threat to the secular republic. In Kemalist perception, the 'reactionaries' and 'separatists' were uniting to proceed with the imperialist powers' plans on Turkey.

*Lecturer, İzmir University of Economics, Faculty of Communication, Turkey.

'Lecturer, İzmir University of Economics, Faculty of Communication, Turkey. 


\section{Introduction}

Kemalism is one of the fields on which a vast literature of political and historical discussion is available. A model of modernisation from above, a successful case of secularisation of a Muslim society, a bureaucratic-corporatist societal model and the ideology of military-bureaucratic elites are a few but many descriptions of Kemalism.

Kemalism takes its name after the founder of the modern Turkish republic, Mustafa Kemal Atatürk. After declaring Turkey a republic in the wake of the First World War in 1923, Kemal singlehandedly governed Turkey, with the help of the military, until his death in 1938, during which time he introduced a secularist and nationalist program, consisting of a series of westernising reforms from transition to Latin script to a compulsory western style dress code. Since his death, the doctrine of Kemalism was escalated to the status of the ruling ideology of Turkish republic and the cult of Atatürk has been the main symbol of the regime, regardless of the varieties of the political tendencies that ruled the country. ${ }^{1}$

This paper follows the trajectory of Kemalism through the republican history from its emergence as the new republic's official ideology to the contemporary erosion of the Kemalist horizon of Turkish state and society. We argue that this erosion occurred under two major challenges to the conventional republican social order since the 1980s, Islamism and Kurdish movement, both of which were established by the Kemalist discourse as the 'others' of modern republic.

After identifying different variants of Kemalist discourse in modern history, including 'classical Kemalism', 'leftwing Kemalism' 'Atatürkism' or 'rightwing Kemalism' and 'neo-Kemalism', the paper focuses on a number of Kemalist columnists' discourse on the recent Kurdish peace initiative of the government. From the discussion on the discursive strategies deployed by Kemalist writers and the analysis of the contextual circumstances in which these statements are made, a major conclusion has been derived that Turkey has irreversibly entered into a post-Kemalist era.

\section{The Genesis of Kemalism}

In order to discern the nature of Kemalism as a political ideology, its selfappointed 'task' of building a modern/western and secular nation-state out of the land and society inherited from the collapsed Ottoman Empire needs to be recalled. This reconstruction necessitated certain practices of annihilation, exclusion and prohibition.

\footnotetext{
${ }^{1}$ See, Ali Kazancigil and Ergun Özbudun, Atatürk: The Founder of Modern State (London: Hirst, 1982) and Andrew Mango, Atatürk (London: John Murray, 1999).
} 


\section{Nationalism}

The question that posed itself as the chronologically primary task of Kemalism was 'national liberation'. Kemal emerged as a nationalist leader in the wake of the Greek forces' landing to Western Anatolia in 1919. Istanbul, the Thrace, the south and east of Anatolia were already under British, Italian and French occupation. The Sevres Treaty that was signed in 1920 between the Ottoman government and the Entente governments ruled the formation of Armenia in the east, a Greek region in the west and a Kurdish region in southeast of the Anatolian peninsula. Kemalist leadership refused this treaty, formed an alternative government in Ankara and mobilised an army to fight the Greek forces until Izmir was taken back in 1922. The Lausanne Treaty that followed the armed conflict abolished the Greek, Armenian and Kurdish regions in favour of a Turkish nation-state.

The Sevres Treaty, with its graphic illustration of partition of Turkey, has an exceptional place in the formation of the Turkish identity. It corresponds to the collective fear of the late Ottoman elites and Muslim masses alike. ${ }^{1}$ This fear had developed gradually in parallel to the contraction of the Imperial lands in Eastern Europe and turned into a nightmare in the last quarter of the $19^{\text {th }}$ Century, when the Balkans and the Caucuses were lost to the rebellious Balkan nations and Russian forces. It was in these conditions that Anatolia and the Thrace were increasingly pronounced by the nationalists as the 'homeland'. However, in this 'last shelter', Christian minorities, particularly the Armenians in the East and Greeks in the West, were demonstrating strong centrifugal tendencies, under the protection and alleged encouragement of the 'great powers'. Consequently, the task of the salvation of the Ottoman state, which would evolve into a nationalist program, defined itself in opposition to the 'Armenian and Greek threat'. This opposition found its shape in a protracted ethno-religious offence, which began with the Ottoman State's 1894 Sassun operation and the subsequent Armenian pogroms of 1895-6 in Istanbul and Eastern Anatolia, continued with the 1914 liquidation of Greek businesses in the Aegean coast and reached to its peak with the Armenian genocide of 1915 .

The Ottoman defeat in the World War I and the subsequent Treaty of Sevres meant the reversal of this 'cleansing' process. Kemalist leadership promised above all that such a reversal would not be allowed and concluded the process with the 1922 population exchange with Greece. The best articulation of the mission of 'national liberation' is probably 1923 address of Kemal $^{2}$ to Cilicia farmers:

Armenians have no place in this noble country. Your country is yours, it belongs to Turks. This country was the Turks' land in

\footnotetext{
${ }^{1}$ A graphic illustration of the Sevres treaty is available at Treaty of Sèvres - Wikipedia, the free encyclopedia- en.wikipedia.org $1024 \times 738$ ).

${ }^{2}$ Mustafa Kemal Atatürk, Atatürk'ün Söylev ve Demeçleri, Volume II . [Atatür's Speeches and Declarations, Volume II.,] (Ankara: Atatürk Kültür, Dil ve Tarih Yüksek Araştırma Kurumu, 1989), 130.
} 
history and therefore it is Turkish and it will remain Turkish to the eternity. (...) This fertile land is purely Turks' country. ${ }^{1}$

The traumatic perception of the Ottoman collapse was inherited by the Kemalists and the Muslim masses populating the land of the new republic to be maintained and reproduced by the national education and everyday nationalist rituals. The foundational myth of Turkish political identity consists of a deep security concern vindicated by a certainty of being encircled by internal and external foes, permanently engaged in a 'master plan' to annihilate the Turkish State and people by dividing their country into parcels and blocking Turkey's development and prosperity. The Sevres Treaty map represents a graphic illustration of this nationalist paranoia which is also referred to as the 'Sèvres Syndrome'. ${ }^{2}$

\section{The Kurdish Uprising and the Sèvres Syndrome}

The new republic therefore inherited a population 'cleansed' from most of the Christian elements. The remaining 'purely' Muslim population, consisting of dozens of different ethnicities, speaking various languages, would be invited by Kemalism ${ }^{3}$ to become Turkish:

There are citizens and members of our nation inside the political and social entity of contemporary Turkish nation, to whom the propaganda of the ideas of being Kurdish, Cyrcassian and even Laz are attempted. But these misnomers, which were the products of the past ages of tyranny, failed to have any influence - apart from suffering - on any members of the nation except for a few brainless reactionaries used by the enemy. Because, the people of these communities like Turkish society in general share the same common past, history, morals and law.

Any resistance to this call for assimilation would be perceived as a threat to the sensitive equilibrium among Muslim ethnicities with a sudden domino effect, which would leave virtually nothing to ground the new national identity on. Consequently, the Sheikh Said rebellion of 1925 triggered the Sèvres Syndrome in terms of a paranoiac fantasy, where the late-Ottoman catastrophe was traumatically re-staged. ${ }^{4}$ The Kurdish resistance to assimilation was

\footnotetext{
1،'In the Clicia (Adana) region, the surviving Armenians returned with the occupation forces to take back what belonged to them. So the notables fell in with the national liberation movement, and even organised it in some places" Taner Akçam.,"The Long Denied Armenian Genocide," Le Monde Diplomatique, September 2001.

${ }^{2}$ Michelangelo Guida, "The Sèvres Syndrome and 'Komplo': Theories in the Islamist and Secular Press," Turkish Studies 9.1 (2008): 37-52.

${ }^{3}$ Afet Inan, Medeni Bilgiler ve M. Kemal Atatürk'ün El Yazılarl, . [Civilized Information and M.Kemal Atatürk’s Manuscripts.], (Ankara: Türk Tarih Kurumu, 1969), 23.

${ }^{4}$ Kurdish resistance to the Kemalist project can be traced back to 1921 Kocgiri rebellion and the opposition of the Teali intellectuals of Istanbul. But noting these oppositions do not amend the fact that Muslim Kurds did rally behind the Kemalist leadership en masse during the 'national struggle'. The 1925 Sheikh Said rebellion, on the other hand, represents an
} 
suppressed violently and the leading figures were executed by the 'Independence Tribunals." Political-cultural techniques of exclusion that accompanied the violence against the Kurdish existence included the annihilation of the word 'Kurd', which the Kurds refer to as the politics of denial.

From 1925 onwards, the state's nationalist discourse gained an increasingly ethno-cultural character to accompany the Kemalist policies of coercive assimilation. Kurdish provinces were turned effectively into a land under colonial administration governed by a 'special inspector' under the shadow of the gendarmes' arms with grave human rights violations. Until the 1950s, the Kemalist administration appointed deputies of the Kurdish provinces, who were mostly of Turkish origin, even excluding those 'Kurdish Turks, who denied their Kurdish identity.'2

The 'Kurd' did not exist in the Kemalist discourse, but the separatist 'Kurdish threat' to the integrity of the Turkish homeland was nevertheless emphasised. The denial of the Kurdish identity was in fact perversely related to its recognition and the potential threat of the formation of the 'real horrific Kurdistan' as Inonu stated in a 'secret East report." ${ }^{3}$ Moreover, as the Sèvres Syndrome implies, this threat was associated with the imperialists' allegedly sustained territorial claims for which the Kurdish rebellions were perceived as subcontracting. In this perception, Sheikh Said rebellion (1925) was connected to the British claims on the Mosul province, Agri rebellion (1930) was a project of the Russians and the Dersim rebellion (1938) was an attempt of the Armenians. ${ }^{4}$ The denial of Kurdish identity has therefore become a constitutive element of Kemalist nationalism, while Kemalism, with its nationalist, secularist and pro-western modernist aspects, was shaping itself as the dominant ideology of the Turkish Republic.

indisputable breaking point regarding the relations between the republican regime and the Kurdish masses. Other remarkable uprisings of the early republican period are 1930 Agri rebellion and 1938 Dersim rebellion.

${ }^{1}$ According to Tunçay the counter insurgency operation against the Sheikh Said rebellion was more costly in human and financial terms than the National Struggle. The rebellious leaders were captured and hanged and severe reprisals were taken in those districts that had participated in the uprising. Mete Tunçay, Türkiye Cumhuriyeti'nde Tek Parti Yönetiminin Kurulmasl 1923-1931, [The Formation of the Monoparty Rule in Turkey (1923-1931).] (Ankara: Yurt, 1981), 136. According to Kurdish sources, military operations resulted in the pillaging of more than two hundred villages, the destruction of over eight thousand houses, and fifteen thousand deaths. Its consequences for the Kurds were catastrophic, almost amounting to 'annihilation' through physical elimination of the entire Kurdish leadership and the destruction of all sources of Kurdish identity. Martin van Bruinessen, "Genocide in Kurdistan? The Supression of the Dersim Rebellion in Turkey (1937-39) and the Chemical War Against the Iraqi Kurds (1988)", in Conceptual and Historical Dimensions of Genocide, ed. George J. Andreopoulos (Pennsylvania: University of Pennsylvania Press, 1994), 149.

${ }^{2}$ Naci Kutlay, Kürt Kimliği Oluşum Süreci (Istanbul: Belge, 1996), 188.

${ }^{3}$ Uğur Mumcu, Kürt Dosyasl, [Kurdish File], (Ankara: Tekin Yayınları, 1995).

${ }^{4}$ Zafer Fehmi Yoruk, "Identity Crisis in Turkey: A Geneological Inquiry into the Exclusion of the Others" (PhD dissertation, University of Essex, 2006). 


\section{Secularism and Modernisation}

The second Kemalist task was secularism. Republican authorities liquidated the Ottoman Ulama (clergy) by prohibiting religious instruction and secularising the national education. Going beyond the Ottoman reformist elites' program, which mainly aimed to modernise and secularise the State with its bureaucracy and military, Kemalists developed a project of modernisation and secularisation of society as a whole. This required the annihilation of traditional religious practices in society. Consequently, the republican regime closed down the Dervish lodges and criminalised the Sufi sects and Tarikats (Islamic orders). The republican laws also prohibited the religious outfit to be worn in public, and ruled a certain dress code, including headgear, for the whole nation.

In their completion of the Ottoman reformists' tasks of modernisation and westernisation, Kemalists disowned the Ottoman past, and made the new generations' access to historical heritage impossible by adopting the Latin script. For these ends, they formed the Turkish History Institute and Turkish Language Institute. The former produced a 'Turkish History Thesis', which 'proved' that Ottoman past was an unwanted accident in the course of Turks' long and glorious history, ${ }^{1}$ while the latter supported this thesis with the 'Sun Language Theory', which asserted that all languages and therefore all civilisations originate from Turkish. ${ }^{2}$

\section{Kemalist Consolidation and the Kurds}

Kemalism consolidated its power as a mono-party regime during the 1930s with the help of a discourse that labelled any resistance to subordination as reaction by the remnants of the ancien régime against revolution. The ethnic tone of the nationalist discourse increased dramatically, being 'enriched' by master-race fantasies. ${ }^{3}$ The unpronounced Kurd was imagined in these fantasies as an inferior entity perceived within a project of assimilation aiming towards a racial hierarchy, as overtly formulated by Kemalist notable Mahmut Esat Bozkurt ${ }^{4}$ in terms of a master-servant relationship:

My personal opinion is that the lords and masters of this country are the Turks. Those who are not of pure Turkish stock have only one right in the Turkish land, it is the right to be servants and slaves.

This 'recognition' required the backwardness of the Kurd and Kurdistan to prevail as a phenomenon of modern Turkey, which could invite the 'uncivilised

\footnotetext{
${ }^{1}$ Zafer Fehmi Yoruk, "Turkish Identity from Genesis to the Day of Judgement" in Politics and the Ends of Identity, ed. Kathryn Dean (Aldershot: Ashgate, 1997), 116.

${ }^{2}$ Ismail Besikçi, Türk Tarih Tezi, Günes Dil Teorisi ve Kürt Sorunu, [Turkish History Thesis, Sun Language Theory and the Kurdish Question.] (Istanbul: Doz, 1977).

${ }^{3}$ Ahmet Y1ldiz, Ne Mutlu Türküm Diyebilene, [How Happy He is Who is Allowed to Say I am a Turk.] (Istanbul: Iletişim, 2001).

4"Mahmut Esat Bey'in Odemis Nutku," [Ödemiş Address of Mr. Mahmut Esat.] Hakimiyet- $i$ Milliye, (Ankara, Turkey), September 19, 1930.
} 
and primitive' Kurds to become 'good servants' as the sole route to assimilation or to 'melting' in the supreme pot of Turkish identity. ${ }^{1}$

In the wake of 1929 depression of world capitalist system, the republican regime initiated an etatist program of economic development grounded upon a bureaucratic-corporatist vision of social solidarity. ${ }^{2}$ Along with the national curriculum, the Kemalist principle of populism generated a political-cultural network of 'people houses' and 'village rooms', in which the republican 'periphery' was indoctrinated by modern cultural values, secularism and nationalism. ${ }^{3}$ In 1940, 'village institutes' were founded for teacher training, where the peasant youth were also instructed in agricultural and industrial skills to lead economic and cultural development in their localities. These efforts yielded a new generation of 'organic intellectuals' of the republic, who would disseminate the Kemalist principles throughout society. ${ }^{4}$

The aim of Kemalism, therefore, was not merely to rule society but to transform the popular belief systems and conventions in favour of modern ones. The military-bureaucratic elites of the new republic found it necessary to form and expand cohesive apparatuses in society and thus establish and maintain Kemalism as the republic's dominant ideology. Under the conditions, where the successive Kurdish rebellions were brutally quelled and the political expressions of Islamic identity were silenced, Atatürk's personality cult was inflated to respond to the spiritual needs of the new republican generations. In this divinised republican horizon, Kemal symbolised all the ideals of the 'nation', including, progress, modernisation and 'civilisation'. All shades of opposition to the mono-party regime would be labelled primarily as a reactionary conspiracy.

\section{After 'Classical' Kemalism}

The 'classical era' of Kemalism concluded with the end of World War II, when the republican authorities decided to side with the US-led 'free world' against the expanding Soviet influence in Europe. In the first free elections of the republican history, the Kemalist Repulican People's Party (CHP) lost power to the centre right Democrat Party (DP). The DP relaxed Kemalism's authoritarian laicism and allowed religious communities' participation in politics through its party networks. As the mechanisation of agriculture and industrialisation through private investment picked up with the Marshall Aid, a certain degree of capitalist development along with rapid urbanisation were observed in Turkish society. As a consequence of siding with the Western Bloc

\footnotetext{
${ }^{1}$ Naci Kutlay, Kürt Kimliği Oluşum Süreci, [The Process of Formation of Kurdish Identity.] (Istanbul: Belge, 1996), 267.

${ }^{2}$ Taha Parla, Ziya Gökalp, Kemalizm ve Türkiye'de Korporatizm, [Ziya Gökalp, Kemalism and Corporatism in Turkey.] (Istanbul: Iletişim, 2006).

${ }^{3}$ Mesut Yeğen, Devlet Söyleminde Kürt Sorunu, [Kurdish Question in the State Discourse.], (Istanbul: Iletişim, 1999).

${ }^{4}$ Zafer F. Yoruk, "Turkish Identity from Genesis to the Day of Judgement," in Politics and the Ends of Identity, ed. Kathryn Dean (Aldershot: Ashgate, 1997), 103-133.
} 
in the Cold War, 'the Russian menace' became the major external threat and the interest of the repressive state apparatuses were exclusively directed against emerging working class and leftwing politics.

\section{Left Kemalism}

In 1960, the Kemalist military toppled the government and legislated a new constitution which partially relaxed the previous anti-communist stance. In these conditions, socialist left grew rapidly throughout the 1960s and 1970s, in parallel to the ascending trade unionisation among the workers and student militancy. Some sectors of the socialist left developed a discourse of left Kemalism, which also catered for the CHP's manoeuvre towards the left. Left Kemalism was inspired by the dependency theory, envisioning independence from 'US imperialism' and finalising the 'democratic revolution'.

Left Kemalism survived as a tendency within the Turkish left. While the CHP opened up towards socialist influences to declare itself a centre-left party, due to their status as the founding party of the Turkish State, they felt obliged to ally with the conservative right against the 'threat of communism', in the last instance. Left Kemalism maintained the Kemalist perspective of assimilation of minorities, unlike some sectors of the socialist left which argued for the right to self-determination of the Kurds.

\section{Atatürkism and Islamist Revival}

The 12 September 1980 coup clarified the military's interpretation of Kemalism as an ideology of national security, which defined the nation in its opposition to a conspiracy of communists, Kurds and Islamists. The military regime concentrated primarily on the suppression of leftist politics, by breaking down working class organisations and the trade union movement in order to eliminate the 'communist threat' and to implement an IMF prescribed 'structural adjustment' program in the economy. The immediate advantage of the economic restructuring was the suppression of the capital accumulation crisis through declining agricultural prices, lower wages and decreased social expenditure. ${ }^{1}$

This structural maintenance of the damaged economy was accompanied by an 'Ataturkist' politico-ideological closure under the military regime. Until 1980, the doctrine of national development had derived freely from a certain strand of socialist discourse, especially in its etatist developmentalism and populism, which contributed to the proliferation of the language games under the Kemalist horizon. However, Ataturkism was designed as a specifically state security discourse signifying the nation in its difference from the 'threat of communism'. The externalisation of the socialist discourse against the background of the growing class conflict and the manifestly threatened social peace from the late 1960 s to 1980 occurred in parallel to a revision in the perception of Kemalism. The revision emerged from the emphasis on national security and tranquillity and the need to fill in the ideological vacuum that was

${ }^{1}$ Çağlar Keyder, State and Classes in Turkey: A Study in Capitalist Development (London and New York: Verso, 1987), 223-228. 
left from the physical elimination of the socialist influence on social and political life of the 1980s' Turkey.

In these circumstances, the 'Turk-Islam Synthesis', which had been produced by conservative-religious intellectuals organised in the 'Hearth of the Enlightened', provided the perfect ideological content for the junta's Ataturkism, with its emphasis on authoritarian politics and social control through the use of cultural and religious codes. ${ }^{1}$ Turk-Islam Synthesis also replaced the 'Turkish History Thesis' as the official grandnarrative of Turkish history. ${ }^{2}$ The revised and Islamised Kemalism of the 1980s appointed the formerly excluded conservative-religious political elements to key positions in the state bureaucracy, particularly in the educational apparatus where the left had previously been influential. ${ }^{3}$

\section{The Return of the 'Kurd' and Neo-Kemalism}

Kurdistan Workers Party (PKK) launched an armed struggle against the Turkish regime in the southeast of Turkey in 1984. In parallel to the increase in their activities, popular support to the PKK grew rapidly not only in the Kurdish provinces but also among the Kurdish population of major cities. In 1991, for the first time in Turkey's history, the People's Labour Party (HEP) was founded with the profile of a Kurdish party. Eleven HEP deputies entered the Parliament, the 'establisment' began to speak of 'Kurdish reality' and the prohibitions on publication in Kurdish language were lifted.

Nevertheless, the Kurdish provinces were under 'Emergency Rule' with heavy military presence. The Kurdish conflict had already generated a Turkish 'war lobby' consisting of ultranationalist elements and mafia chiefs in an alliance with the militarist 'deep state' elements. The military conflict intensified in the wake of the Gulf War in 1992 and the State returned to its original 'one nation' and 'unitary state' discourse, which accompanied an escalation of military violence with immense human rights violations. ${ }^{4}$ Turkish army conducted tens of cross-border operation to eliminate the PKK bases in Northern Iraq. In 1999, the leader of the PKK, Abdullah Öcalan, was captured and the Turkish State felt itself victorious, as is evident in the indictment of the Kurdish party HADEP:

\footnotetext{
${ }^{1}$ Zafer Fehmi Yörük, Identity Crisis in Turkey A Genealogical Inquiry into the Exclusion of the “Others" (Saarbrücken: LAP Lambert Academic Publishing, 2010), 269-281.

${ }^{2}$ Etienne Copeaux, Türk Tarih Tezi'nden Türk Islam Sentezi'ne, [From Turkish History Thesis to Turk Islam Synthesis.,] (Istanbul: Tarih Vakfi Yurt Yayınları, 1998).

${ }^{3}$ Erkan Akin and Omer Karasapan, "The 'Turkish-Islamic Synthesis," Middle East Report, no. 153 (July-August, 1988): 18.

${ }^{4}$ The Kurds lost more than 30,000 lives, mostly civilians, in two decades, and millions of them were evicted from their torched villages to become refugees in major cities. For the records of human rights violations see Amnesty International annual reports from 1990 onwards.
} 
There is only one identity in Turkey, that is, the Turkish identity. Demands for recognition of the Kurdish identity are but the first step of a devious attempt to divide the country. ${ }^{1}$

\section{Neo-Kemalism}

The intensification of the Kurdish conflict in the 1990s triggered nationalist reactions among Turkish society. ${ }^{2}$ In the discourse of the two centre left parties, CHP and Democratic Left Party (DSP), nationalism and authoritarian secularism were gaining increasingly more emphasis.

On the opposite side of the political spectrum, the popularity of the proIslamist Welfare Party (RP) was on the rise. The synchronic ascendance of Kurdish movement and Islamism triggered the originary Kemalist mental association of Kurdish 'banditry' and the 'reactionary threat'. Kemalism, therefore, restructured itself in the 1990s in defence of the unitarian State and secularism against the ascending Kurdish movement and the Islamist revival.

The RP won the 1995 elections and formed a conservative right coalition, under the leadership of their Islamist leader, Necmettin Erbakan in 1996. This was the moment when the centre left parties overtly called the 'guardians of the republic', including urban middle class masses and the military, to the 'duty' of protection of Kemalist foundations of the republic. The call found its reflection and following a military declaration on 28 February 1997, the RP led coalition collapsed. This development was followed by the closure of the RP by the Constitutional Court's decision.

The 28 February intervention led to a split in pro-Islamist politics. The charismatic mayor of Istanbul, Recep Tayyip Erdoğan, separated his followers from the 'old guard' to form the Justice and Development Party (AKP) in 2001 with the profile of a moderate Islamist party. Contradicting with their tradition, the AKP promised Turkey's full integration with the neoliberal capitalist networks and with the European Union through economic privatisation and political democratisation. In the first general elections that they entered in November 2002, the AKP won a clear majority to form the government.

The 2003 US invasion of Iraq and the tangible existence of the Kurdistan Regional Government in Northern Iraq triggered the Sevres Syndrome once again. ${ }^{3}$ For both Kemalists and hard-line nationalists, American imperialism, the Kurds and the Islamists were coming together to restructure the Middle East, including the partition of Turkey according to the Sevres map.

\footnotetext{
${ }^{1}$ Turkish State Department, "Briefing no.1228" (Ankara: Turkish State Department, February 1, 1999), 10.

${ }^{2}$ This phenomenon is described as the "dark spring of nationalism" by Tanil Bora, Milliyetçiliğin Kara Baharı (Istanbul: Birikim, 1995).

${ }^{3}$ Guida, "The Sèvres Syndrome and 'Komplo': Theories in the Islamist and Secular Press", 42.
} 


\section{Kurdish Peace and Kemalist Journalism}

Since May 2009, when President Abdullah Gül declared that the Kurdish question was 'the number one issue of Turkey', the AKP government has been engaged in peace initiatives to bring the Kurdish conflict to a decisive end. The initial attempt seemed to have failed under fierce criticism from the opposition but a second attempt was launched in 2012 .

The peace process has caused a controversial debate between the progovernment and Kemalist media outlets. Kemalist reporters and writers argue that the government's peace plan is the beginning of an end to Turkey's national unity. Moreover, holding talks with Öcalan is presented as the biggest assault on Turkish nationalism and a compromise of the monolithic principles of the Republic of Turkey. For the Kemalist journalists, the threat posed by the Kurdish solution process to the unity of nation doubled by the fact that it is initiated by the AKP government, since AKP represents a serious threat to the secular republic. In Kemalist perception, the 'reactionaries' and 'separatists' unite to implement the imperialist powers' plans on Turkey.

This section, focuses on Kemalist journalism's discourse on the Kurdish peace process. The sample consists of a selection of columns and opinion pieces by Kemalist writers from Hürriyet, Sözcü and Cumhuriyet newspapers between 21 March and 30 March 2013. This period is particularly important because on 21 March 2013, the PKK leader Abdullah Öcalan, issued a letter from prison to be read aloud at the Kurdish New Year (Newroz) celebrations in Diyarbakır. In this letter, Öcalan declared the end of armed struggle and the beginning of peace with the Turkish government. A heated debate emerged around this letter about the peace deal between the Turkish government and the PKK and its ramifications for the future of Turkey.

\section{Naming the Kurdish Peace Process}

Kemalist journalists have taken a hard-line opposition towards the letter, expressing their concerns over 'national unity', which is explicitly referred to in all the columns analysed. Sözcü columnist, Uğur Dündar ${ }^{1}$ makes the following points:

No negotiation with the terrorists; weapons would be surrendered as the precondition of peace; 'one nation, one flag, one state' would be the uncompromised principle... (Öcalan's) letter shows that all these promises were fairy tales. Let's name the process correctly: it is not a solution process but a process of disintegration. What happened in Diyarbakır during the recent days was the formation of a federal State, like the one in Northern Iraq. This scenario has been forced onto Tayyip Erdoğan by the US and Israel. Prime Minister Erdoğan and Apo (Öcalan) act in a scenario which was penned by the superpowers.

${ }^{1}$ Uğur Dündar, "Çözü(lü)m Süreci!" Sözcü, [The Process of Disintegration.], (Istanbul, Turkey), March 23, 2013. 
Cumhuriyet writer Mümtaz Soysal ${ }^{1}$ presents a similar argument:

The 'historical' letter ... aims to lay the grounds for the partition and sell-out of the Republican Turkey, by ignoring its fundamental principles. (...) Erdoğan despises and challenges Kemalism. His vision has been to radically transform Mustafa Kemal's modern republic into an Ottoman State, consisting of provincial divisions. This project dynamites the very foundations of the Turkish Republic.

The two Kemalist writers above argue that opening process could pave the way for those to implement their 'vicious plans' to divide the country along ethnic lines. Very often, the USA and Israel are depicted as outside enemies, in collaboration with the internal enemies, aim to partition of Turkey and to reshape the Middle East, in order to pursue their own interests in the region. Thus, for the Kemalist journalists Kurdish peace process is a pretext for hidden agendas of the enemies of Turkey. Such discursive construction of the peace process reproduces the nationalist discourse since the establishment of the Republic of Turkey which had always accused the Kurds' demands for political and cultural rights as being part of the conspiracy of the internal and external enemies to divide Turkey.

This international perception, in which the external 'great powers' hold the top position and order the Prime Minister and the PKK leader to implement the US and Israeli plans constitutes the general framework in which Kemalism understood and explicated the Kurdish peace process.

\section{History Repeats Itself}

Kemalist writers often refer to the process of the collapse of the Ottoman Empire, when discussing the contemporary Kurdish peace process. They connect many aspects of the two events through historical (but rather anachronistic) analogies.

The letter affair coincided with the anniversary of the 1915 Gallipoli war. The pro-Kurdish BDP deputy Sırr Sakık issued a statement saying Kurds and Turks fought in Gallipoli side by side against foreign invasion. Cumhuriyet writer Cüneyt Arcayürek ${ }^{2}$ finds the Prime Minister's speech on the same issue having striking parallels with Sak1k's claim:

Following the commencement of the new Kurdish opening under the name of solution process, Prime Minister delivered a speech in Gallipoli proving that he was in the same lane with Sirrı Sakık and saying "Gallipoli is not the victory of one ethnic group, race or tribe". This way the Prime Minister denied that Gallipoli was a victory of Turkish nation, like the BDP.

\footnotetext{
${ }^{1}$ Mümtaz Soysal, "Laflar ve Gerçekler," Cumhuriyet, [Words and Truths.] (Istanbul, Turkey), March 22, 2013.

${ }^{2}$ Cüneyt Arcayürek, "18 Mart'ta İki Olay,” [Two Events on 18 March.], Cumhuriyet (Istanbul, Turkey), March 22, 2013.
} 
Arcayürek then counter numbers of historical research into the origins of the fallen Ottoman soldiers presumably to prove the Turkish ethnic origin of the martyrs:

Only two percent of the fallen soldiers come from the southeast Turkey. Would these figures shame the Prime Minister or his sidekick BDP, I do not know.

For Hürriyet writer Y1lmaz Özdil ${ }^{1}$, peace process should evoke the tragic collective memoirs of the invasion of Izmir and Anatolia in the wake of the World War I. He writes:

What is happening today reminds us of the year 1919. Izmir was invaded. Colonel Ali Nadir Pasha, the head of the combat troops in Izmir, and Governor Ahmet İzzet Bey ordered the troops not to resist to the occupying allied powers, and give up arms. On 15 May 1919, while the Greeks of Izmir welcomed the Greek troops, Hasan Tahsin, a journalist, shot a Greek soldier. (...) Why do I remind you of all these? It is because what is happening today is the same: the rulers of this country surrender without firing a single shot, behaviour, so similar to the attitude of the rulers of those days.

Özdil's discourse implies that the contemporary peace process is conceding defeat of the Turkish side; it is not peace but surrender.

\section{Religion Replacing the Principle of Nationalism}

Kemalists collectively frowned upon the absence of the Turkish flag in the Newroz rally in Diyarbakir where Öcalan's message was read aloud. This absence was taken as an indication of the abolition of the principle of nation that allegedly cements the society together. Bekir Coşkun ${ }^{2}$ observes:

The terrorist and the Prime Minister unite in the principle of 'Islam'. (...) Instead of Turkishness and nationalism, the bond that will keep this country together is now Islam. It is because of this that there were no Turkish flags in that square (where Diyarbakır Newroz rally took place).

Similarly, Güray Öz $z^{3}$ from Cumhuriyet says the following:

\footnotetext{
${ }^{1}$ Yılmaz Özdil, "Biji izlemeye devam edin,”, [Carry on Following Us.], Hürriyet (Istanbul, Turkey), March 23, 2013.

${ }^{2}$ Bekir Coşkun, "Çarşafa Dolandırdı," Sözcü, [Wrapped up in the Veils.], (Istanbul, Turkey), March 21, 2013.

${ }^{3}$ Güray Öz, "Hele köprüyü bir geçelim," [Let's First Cross the Bridge.], Cumhuriyet (Istanbul, Turkey), March 22, 2013.
} 
The idea that has been vocally enunciated recently is the Islamist perception that the concept of millet denotes religious unity rather than nation. Erdoğan and Öcalan speak in harmony on this issue.

\section{'We (Turks and Kurds) lived in Peace before}

This discourse suggests that AKP's recognition of Kurdish identity leads to a civil war in Turkey. Because, before the peace process, the Turks and the Kurds did not ask each other's ethnicity and lived as one nation. As Coşkun ${ }^{1}$ describes Turkey before the peace process:

A country where nobody asks the other 'are you Turkish or Kurdish'; where common businesses are formed; where inter-ethnic marriages took place; where young men shared the same barracks, the children the same school, same language, same flag and same national anthem.

Coşkun continues, "...for the first time people who share the same city, the same neighbourhood and the same market place began to attack each other". With the peace process, therefore, the people began to question their neighbours' ethnic origins and this endangers national unity:

Look at Turkey's situation in the recent few days. A war zone. (...) What is the meaning of so many street clashes in dozens of cities? (...) He (probably Erdoğan) is ignorant. He searches for internal peace in the wrong place, by ignoring the divine values such as national days, army, flag, language and the laws of revolution. By elevating the separatist terrorists he destroyed society's nerve system. While trying to obtain peace with Qandil $^{2}$ he harmed the peace in Anatolian cities and towns.

We Support Peace but...

An important Kemalist argument is that the AKP engage in this peace process not for the interests of the country but, in addition to the imperialist interests, the Prime Minister's dictatorial aspirations. The primary expectation of AKP is observed in these commentary as the transition to a presidential system through constitutional change. Emre Kongar ${ }^{3}$ observes in Cumhuriyet that "The bargain is: give me the position of Sultan and take autonomy." This argument suggests that the pro-Kurdish BDP deputies would vote along with the AKP deputies in the Parliament for the legislation of the presidential system, which Kongar views a return to the Ottoman regime of Sultanate.

\footnotetext{
${ }^{1}$ Bekir Coşkun, “Acı Yazı,” [Bitter Script.], Sözcü (Istanbul, Turkey), March 22, 2013.

${ }^{2}$ Qandil mountain in northern Iraq is where the PKK headquarters is located.

${ }^{3}$ Emre Kongar, "Adalet Olmadan Barış Olur mu?", [Could There be Peace Without Justice.], Cumhuriyet (Istanbul, Turkey), March 21, 2013.
} 
Cumhuriyet writer Şükran Soner ${ }^{1}$ states that she cannot ignore the call for peace, but suspects that the current initiative has two major problems: the religious character and the Prime Minister's personal aspirations.

The most optimistic comment would be the search of people who shared the same history, the same land and cultural past to meet around the axis of "multiculturalism". But how is this going to happen? By meeting under the citizenship (...) with one official language along with the right to learn and use the mother-tongue? Or at the common denominator of religious brotherhood, by emphasising religious identity, which AKP finds very useful in agreeing with the Kurds? Or, in these bargain for transition to a civilian dictatorial order, the hopes of the Turks and the Kurds to find peace will be doomed once again?

In this discourse Soner goes beyond the limits of Kemalism to accept the necessity of peace. The Kurdish claims, in this perception, are reduced to linguistic rights, and the shape of the recognition has certain Kemalist limits. The peace that Soner imagines allows the Kurds to speak Kurdish on the condition that Turkish remains the official language. Given that the Kurds of Turkey already speak Kurdish, Soner's peace only promises education in Kurdish. The Kurdish demands, on the other hand, include a list of other issues in addition to linguistic rights and these are completely ignored by Soner's gaze. Soner shares Kongar's concerns regarding the Prime Minister's aspirations to become a dictator. Another concern is AKP's framework of peace grounded upon the brotherhood of Muslims.

In conclusion, the Kemalist writers saw two threats to modern Turkish republic, ethnic division and desecularisation, embodied in the peace process. Placing national unity at the core of the debate, the Kemalist writers completely ignored Kurdish people's political demands. As such Kemalist media have played a significant role in framing the Kurdish peace process in terms of threat, and contributed to the problem oriented reporting of Kurdish liberation. The Kurdish view did find itself a space in the columns. Framing the Kurdish peace process in relation to the threat to the national unity not only aims to delegitimise the peace process, but also leaves no room for the Kurds' legitimate identity demands to be debated.

\section{Kemalism without Generals, or, Post-Kemalism}

Prior to AKP's peace initiative the Kemalist 'guardians of the republic' conceded a fatal blow. Following a series of victories in local and general elections, AKP managed to pass a series of legislation ruling the elimination of the role of the military in politics. The Ergenekon and the subsequent Balyoz

${ }^{1}$ Şükran Soner, "Barış gökten zembille inmez,", [Peace Would not be Presented to us from Heavens.] Cumhuriyet (Istanbul, Turkey), March 21, 2013. 
trials put most of the military elite, including a former Chief of General Staff, behind the bars, being charged with conspiring to overthrow the constitutional government. The connection between the elimination of the military power and the peace process is observed by Kongar ${ }^{1}$ as follows:

The syncronic processes of Silivri $^{2}$ and Imrali $^{3}$ are deeply intertwined. Public perception of these developments is also in this direction given the popular catchphrase: "life sentence to Silivri; dialogue with Imralı".

Democratisation through demilitarisation was accompanied by a gradual Islamisation through de-secularisation of the State and society. In addition to the observable changes such as the lifting of the headscarf ban in public service, the national curriculum has been reformed allowing more religious instruction in the expense of Kemalist mythology. On the Kurdish front, in addition to the peace initiative, important economic ties, including contracts of oil trade, have been established with the Kurdish administration in Northern Iraq.

The AKP reign thus managed to overturn many Kemalist obsessions in Turkish State, by acting directly towards the materialisation of many elements of the paranoiac scenarios of the Sevres Syndrome, as Guida ${ }^{4}$ observes:

The AKP party program does not show any signs of paranoia and, actually, its economic and foreign policies are very pragmatic; thus they do not seem to be influenced at all by the Sèvres Syndrome.

The recognition of the Kurdish identity and the ongoing Islamisation of the State and society $^{5}$ against the secularist credentials imply the end of

\footnotetext{
${ }^{1}$ Emre Kongar, "Aydınlanma,", [Could There be Peace Without Justice.], Cumhuriyet (Istanbul, Turkey), March 22, 2013.

${ }^{2}$ Silivri Prison is where the suspects and convicts of the Ergenekon and Balyoz trials are jailed. ${ }^{3}$ Imralı Island is where the captured leader of the PKK, Abdullah Öcalan, is held.

${ }^{4}$ Guida, "The Sèvres Syndrome and 'Komplo': Theories in the Islamist and Secular Press", 47.

${ }^{5}$ There are arguably limits of AKP's pragmatism both in terms of the Kurdish peace process and foreign policies. In December 2009, for example, the first attempt of peace process was axed by the government with a wave of arrests of Kurdish politicians and activists. "KCK Operasyonun'da 28 tutuklama" BBC Türkçe, last modified December 25, 2009, http://www. bbc.co.uk/turkce/haberler/2009/12/091225 turkey kurds.shtml. This move occurred amidst fierce debate over Turkey's new foreign policy orientations under the then Minister of Foreign Affairs Ahmet Davutoğlu, see Uğur Özgöker and Sezin İba, "Uluslararasu İlişkiler ve Türkiye'nin Yeni Dış Politikası," in 21.Yüzyılda Çağdaş Türk Dış Politikası ve Diplomasisi, ["International Relations and Turkey's New Foreign Policy" ed. Hasret Çomak (Kocaeli: Umuttepe Yayınları, 2010), 79-101. For a detailed analysis of Davutoğlu's foreign policy also see Baskın Oran, Türk Dış Politikası, Cilt 3 (2001-2012) (Istanbul: Iletişim, 2013). Davutoğlu's "neo-Ottomanism" was viewed as the indication of a "shift-of-axis" from the prospect of integration with Europe to a new emphasis on relations with the Muslim governments and societies of the Middle East, see Soner Çağaptay, "Is Turkey leaving the West?," Foreign Affairs, last modified October 26, 2009, http://www.foreignaffairs.com/arti cles/65661/soner-cagaptay/is-turkey-leaving-the-west. Also see, Valeria Giannotta, "Turkish
} 
Kemalism's reign as the official ideology of the Turkish State. The ongoing electoral support to the AKP government indicates the popular support for the de-Kemalisation of Turkey.

Although Kemalists never managed to be in full power since 1950, Kemalism has been the dominant ideology of republican Turkey, with its goals of 'civilisation', secularisation and becoming one nation. When these principles gradually eroded through the 1990s, Kemalism still remained as the official ideology of the State. In 2000s, however, the paradigmatic shift of the republican era seems to have completed with the elimination of the power of the military as the 'guardians of the republic'. Although it has been in opposition for most of the modern history, Kemalism has always been an authoritarian discourse, containing in itself the threat of military intervention. Kemalists, when protesting the policies of the governments often called the military to perform its 'duty'. This was not a bluff, given the history of military coups and interventions of $20^{\text {th }}$ Century. The possibility that this threat does not exist anymore would mean that Kemalism is no longer the official ideology of the Turkish State. In spite of losing its dominant or official status, Kemalism did not fade away completely as an ideology. On the contrary, an increase can be observed in the popularity of Kemalist symbols among society in opposition to the various problems that government policies generate. But such civilian popularity lacks official backing, particularly from the military, and this is precisely the post-Kemalist condition.

\section{Conclusion}

Kemalism went through a few stages during the history of republic, during which it has been maintained as the ruling ideology of the State. With the challenges of the Islamist and the Kurdish identities in recent decades this exceptional status of Kemalism has been weakened and with the elimination of military's role in politics, Kemalism's determination of the State discourse and policies has also come to an end. The Kemalist discourse survives in these post-Kemalist conditions as a conservative discourse, which, instead of offering a vision for the future of society, merely emphasises the need for the protection of the 'orthodox' Kemalist principles of Turkey.

Foreign Policy Evolution and Goals Under the AKP Government," Balkananalysis, last modified January 19, 2012, http://www.balkanalysis.com/turkey/2012/01/19/turkish-foreignpolicy-evolution-and-goals-under-the-akp-government/. After a short interval, however, the Kurdish peace process recommenced, although with observable fluctuations, as expected. Similarly, regarding the foreign policy, Turkey's new turn did not mean the sacrifice of its Western orientation. See, Cengiz Çandar, “Turkey's 'soft power' strategy: A new vision for a multi-polar world," in Foundation for Political, Economic and Social Research, SETA Policy Brief, no.38 (2009): 11. In both respects, therefore, AKP maintains it pragmatic approach and continues to lack any signs of paranoia or of being haunted by the Sévres Syndrome. 


\section{Bibliography}

Akcam, Taner. "The Long Denied Armenian Genocide". In Le Monde Diplomatique, September 2001.

Akcam, Taner. From Empire to Republic: Turkish Nationalism and the Armenian Genocide. London and New York: Zed Books, 2004.

Akin, Erkan and Karasapan, Omer. "The Turkish-Islamic Synthesis". Middle East Report, no. 153 (July-August, 1988): 12-15.

Arcayürek, Cüneyt. "18 Mart'ta İki Olay." [Two Events on 18 March.] Cumhuriyet, (Istanbul, Turkey), March 22, 2013.

Atatürk, Mustafa Kemal. Atatürk'ün Söylev ve Demeçleri, Volume II. [Atatür's Speeches and Declarations, Volume II.] Ankara: Atatürk Kültür, Dil ve Tarih Yüksek Araştırma Kurumu, 1989.

Besikçi, İsmail. Türk Tarih Tezi, Günes Dil Teorisi ve Kürt Sorunu. [Turkish History Thesis, Sun Language Theory and the Kurdish Question.] Istanbul: Doz, 1977.

Bora, Tanıl. Milliyetçiliğin Kara Baharı. [The Black Spring of Nationalism.] Istanbul: Birikim, 1995.

Bruinessen, Martin van. "Genocide in Kurdistan? The Suppression of the Dersim Rebellion in Turkey (1937-38) and the Chemical War Against the Iraqi Kurds (1988)". In Conceptual and Historical Dimensions of Genocide, edited by George J. Andreopoulos, 141-170. Pennsylvania: University of Pennsylvania Press, 1994.

Copeaux, Etienne. Türk Tarih Tezi'nden Türk Islam Sentezi'ne. [From Turkish History Thesis to Turk Islam Synthesis.] Istanbul: Tarih Vakfi Yurt Yayınları, 1998.

Coşkun, Bekir. "Çarşafa Dolandırdı." [Wrapped up in the Veils.] Sözcü (Istanbul, Turkey), March 21, 2013.

Coşkun, Bekir.“Acı Yazı.” [Bitter Script.] Sözcü (Istanbul, Turkey), March 22, 2013.

Çandar, Cengiz. "Turkey's 'soft power' strategy: A new vision for a multi-polar world". In Foundation for Political, Economic and Social Research, SETA Policy Brief, no.38 (2009): 3-12.

Dündar, Uğur. “Çözü(lü)m Süreci!” [The Process of Disintegration.] Sözcü (Istanbul, Turkey), March 23, 2013.

Giannotta, Valeria. "Turkish Foreign Policy Evolution and Goals under the AKP Government.” Balkananalysis. Last modified January 19, 2012. http://www.balk analysis.com/turkey/2012/01/19/turkish-foreign-policy-evolution-and-goals-unde r-the-akp-government/.

Guida, Michelangelo. "The Sèvres Syndrome and 'Komplo': Theories in the Islamist and Secular Press." Turkish Studies 9.1 (2008): 37-52.

Inan, Afet. Medeni Bilgiler ve M. Kemal Atatürk'ün El Yazılart. [Civilized Information and M.Kemal Atatürk's Manuscripts.] Ankara: Türk Tarih Kurumu Yayını, 1969.

Kazancigil, Ali and Özbudun, Ergun. Atatürk: The Founder of Modern State. London: Hirst, 1982.

"KCK Operasyonun'da 28 tutuklama." [28 Arrests in KCK Operation.] BBC Turkish. Last modified December 25, 2009. http://www.bbc.co.uk/turkce/haberler/2009/ 12/091225_turkey_kurds.shtml.

Keyder, Çağlar. State and Classes in Turkey: A Study in Capitalist Development. London and New York: Verso, 1987.

Kongar, Emre. "Adalet Olmadan Barış Olur mu?" [Could There be Peace Without Justice.] Cumhuriyet (Istanbul, Turkey), March 21, 2013.

Kongar, Emre. "Aydınlanma," [Enlightenment.] Cumhuriyet (Istanbul, Turkey), March 22, 2013. 
Kutlay, Naci. Kürt Kimliği Oluşum Süreci. [The Process of Formation of Kurdish Identity.] Istanbul: Belge, 1996.

"Mahmut Esat Bey'in Ödemiş Nutku." [Ödemiş Address of Mr. Mahmut Esat.] Hakimiyet-i Milliye (Ankara, Turkey), September 19, 1930.

Mango, Andrew. Atatürk. London: John Murray, 1999.

Mumcu, Uğur. Kürt Dosyasi, [Kurdish File] Ankara: Tekin Yayinlari, 1995.

Oran, Baskın. Türk Dış Politikası, Cilt 3 (2001-2012). [Turkish Foreign Policy, Volume 3 (2001-2012).] Istanbul: Iletișim, 2013.

Öz, Güray. "Hele Köprüyü Bir Geçelim.” [Let's First Cross the Bridge.] Cumhuriyet (Istanbul, Turkey), March 22, 2013.

Özdil, Y1lmaz. "Biji İzlemeye Devam Edin." [Carry on Following Us.] Hürriyet (Istanbul, Turkey), March 23, 2013.

Özgöker, Uğur and Iba, Sezin. "Uluslararası İlişkiler ve Türkiye'nin Yeni Dış Politikası". In 21.Yüzyılda Çă̆daş Türk Dış Politikası ve Diplomasisi, ["International Relations and Turkey's New Foreign Policy". In Contemporary Turkish Foreign Policy and Diplomacy in the 21st Century.] edited by Hasret Çomak, 79-101. Kocaeli: Umuttepe Yayınları, 2010.

Parla, Taha. Ziya Gökalp, Kemalizm ve Türkiye'de Korporatizm. [Ziya Gökalp, Kemalism and Corporatism in Turkey.] Istanbul: Iletişim, 2006.

Soner Çağaptay. "Is Turkey leaving the West?" Foreign Affairs. Last modified October 26, 2009. http://www.foreignaffairs.com/articles/65661/soner-cagaptay/ is-turkey-leaving- the-west.

Soner, Şükran. "Barış Gökten Zembille İnmez." [Peace Would not be Presented to us from Heavens.] Cumhuriyet (Istanbul, Turkey), March 21, 2013.

Soysal, Mümtaz. "Laflar ve Gerçekler." [Words and Truths.] Cumhuriyet (Istanbul, Turkey), March 22, 2013.

"Treaty of Sèvres" - Wikipedia, the free encyclopaedia en. wikipedia.org1024 $\times 738$.

Tunçay, Mete. Türkiye Cumhuriyeti'nde Tek Parti Yönetiminin Kurulmasl (19231931). [The Formation of the Monoparty Rule in Turkey (1923-1931).] Ankara: Yurt, 1981.

Turkish State Department, "Briefing no.1228" (Ankara: Turkish State Department, February 1, 1999).

Yeğen, Mesut. Devlet Söyleminde Kürt Sorunu. [Kurdish Question in the State Discourse.] Istanbul: Iletişim, 1999.

Yıldız, Ahmet. Ne Mutlu Türküm Diyebilene. [How Happy He is Who is Allowed to Say I am a Turk.] Istanbul: Iletişim, 2001.

Yoruk, Zafer F. "Turkish Identity from Genesis to the Day of Judgement". In Politics and the Ends of Identity, edited by Kathryn Dean. 103-133. Aldershot: Ashgate, 1997.

Yoruk, Zafer F. "Politik Psise Olarak Turk Kimligi". In Modern Turkiye'de Siyasi Düşünce, Vol. IV, Milliyetcilik, ["Turkish Identity as Political Psyche". In Political Thought in Modern Turkey, Vol.V: Nationalism.] edited by Tanıl Bora. 309-324. Istanbul: Iletisim, 2002.

Yoruk, Zafer F. "Identity Crisis in Turkey: A Geneological Inquiry into the Exclusion of the Others." PhD dissertation, University of Essex, 2006.

Yoruk, Zafer F. Identity Crisis in Turkey A Genealogical Inquiry into the Exclusion of the "Others." Saarbrücken: LAP Lambert Academic Publishing, 2010. 
